\title{
EVALUATION OF ANTIDIABETIC ACTIVITY OF LEAF EXTRACT OF OCIMUM SANCTUM LINN. IN ALLOXAN-INDUCED NON-INSULIN DEPENDENT DIABETIC RATS
}

\author{
Tarali Devi1, Pallavi Bordoloi², Mangala Lahkar ${ }^{3}$ \\ ${ }_{1}^{1}$ Assistant Professor, Department of Pharmacology, Assam Medical College and Hospital, Dibrugarh, Assam. \\ ${ }^{2}$ Assistant Professor, Department of Pharmacology, Assam Medical College and Hospital, Dibrugarh, Assam. \\ 3 Professor, Department of Pharmacology, Gauhati Medical College and Hospital, Guwahati, Assam.
}

\section{ABSTRACT}

\section{BACKGROUND}

To study the antidiabetic activity of ethanolic extract of leaves of Ocimum sanctum Linn. (EEOS) in alloxan-induced non-insulin dependent diabetic rats.

\section{MATERIALS AND METHODS}

Wistar Albino rats weighing 150-200 grams were grouped into five equal groups taking six animals in each group. Group A served as control (Normal), Group B as diabetic control, Group C and D received EEOS at a dose of $250 \mathrm{mg} / \mathrm{kg}$ and $500 \mathrm{mg} / \mathrm{kg}$ orally respectively, Group E was given standard drug (Glibenclamide $5 \mathrm{mg} / \mathrm{kg}$ ) for 28 consecutive days and the effect of the ethanolic extract of Ocimum sanctum leaves on blood glucose levels was measured at regular intervals. At the end of the study, blood samples were collected from all the animals for biochemical estimation.

\section{RESULTS}

The result indicate that the test drug compound EEOS has statistical significance $(\mathrm{p} \leq 0.05)$ and sustained oral hypoglycaemic activity comparable with the hypoglycaemic effect of Glibenclamide.

\section{CONCLUSION}

The study confirms that EEOS has antidiabetic activity against alloxan-induced diabetic rats. It could be a novel antidiabetic agent and also a dietary adjunct for the management of type 2 diabetes and its complication. Further studies are required to confirm the antidiabetic activities of individual phytoconstituents of Ocimum sanctum.

\section{KEYWORDS}

Ocimum sanctum, Antidiabetic Activity, Alloxan, Glibenclamide, Phytochemical Constituents.

HOW TO CITE THIS ARTICLE: Devi T, Bordoloi P, Lahkar M. Evaluation of antidiabetic activity of leaf extract of Ocimum sanctum linn. in alloxan-induced non-insulin dependent diabetic rats. J. Evolution Med. Dent. Sci. 2016;5(86):6425-6428, D0I: $10.14260 /$ jemds/2016/1453

\section{BACKGROUND}

Diabetes mellitus also known as 'Madhumeha' in Sanskrit represent a heterogeneous group of disorders, which has plagued the mankind since the ancient civilisation. It is a chronic metabolic disorder with micro and macrovascular complications, characterised by chronic hyperglycaemia and disturbances of carbohydrates, fats and protein metabolism associated with absolute or relative deficiencies in insulin secretion and/or insulin action.[1] It has become the third killer of the health of mankind along with cancer, cardiovascular and cerebrovascular disease. Diabetes mellitus is a global health crisis which has been persistently affecting the humanity, irrespective of the socio-economic profile and geographical location of the population. The prevalence of diabetes mellitus is expected to reach up to $4.4 \%$ in 2030 and highest occurrence is found in India, China and USA.[2]

Financial or Other, Competing Interest: None.

Submission 21-09-2016, Peer Review 15-10-2016,

Acceptance 21-10-2016, Published 27-10-2016.

Corresponding Author:

Dr. Tarali Devi,

Assistant Professor,

Department of Pharmacology,

Assam Medical College and Hospital,

Dibrugarh, Assam.

E-mail: drtaralidevi@gmail.com

DOI: $10.14260 /$ jemds/2016/1453
According to International Diabetes Federation (IDF) $7^{\text {th }}$ edition, the number of individuals with diabetes in 2015 crossed 415 million and by 2040 this will rise to 642 million. [3] Though advancement is made in the field of modern medicine to cure diabetes, still there is increasing demand by patients to use natural products with antidiabetic activity due to the side effects associated with the use of insulin or oral hypoglycaemic agents. In recent findings, extracts of various plant materials are capable of decreasing blood sugar level in experimental animal models and are considered to be less toxic than synthetic ones. ${ }^{[4]}$

Ocimum sanctum Linn., commonly known as tulsi or tulasi in hindi and holy basil or sacred basil, belonging to family Lamiaceae is a strongly scented small annual herb, about $30-60 \mathrm{~cm}$ tall with hairy stems and simple opposite green leaves. Leaves have petioles and are ovate, up to $5 \mathrm{~cm}$ long, usually slightly toothed. Leaf colour ranges from light green (Rama tulsi) to dark purple (Krishna tulsi). Flowers are purplish in elongate racemes in close whorls.[5] It grows wild in the tropics and warm regions. In India, it is grown throughout the country from Andaman and Nicobar Island to the Himalayas up to 1800 metres above the sea level. It is also abundantly found in Malaysia, Australia, West Africa and some of the Arab countries.

\section{Traditional Uses}

Ocimum sanctum Linn. (Tulsi) is known as 'the elixir of life' since it promotes longevity. Different parts of the plant are traditionally used for common cold, headache, earache, sore 
throat, bronchitis, malarial fever, antidote for snake bite and scorpion sting, fatigue, skin, wound infection, etc.[6]

\section{Pharmacological Activities}

Several medicinal properties have been attributed to Ocimum sanctum Linn. Different parts of the plant, i.e. leaves, flowers, stem, root, seeds, etc. are known to possess therapeutic potential like analgesic, expectorant, anti-asthmatic, antimicrobial, anti-emetic, antidiabetic, anti-fertility, anti-cancer, diaphoretic, hepatoprotective, hypotensive, hypolipidaemic, anti-stress, etc. ${ }^{[7,8]}$

\section{Phytochemical Constituents}

The chemical composition of Ocimum sanctum Linn. is highly complex, containing many nutrients and other biologically active compounds. The leaves of Ocimum sanctum Linn. contain $0.7 \%$ volatile oil comprising about $71 \%$ eugenol and $20 \%$ methyl eugenol. The oil also contains carvacrol and sesquiterpene hydrocarbon caryophyllene. Fresh leaves and stem of Ocimum sanctum extract yielded some phenolic compounds such as cirsilineol, circimaritin, isothymusin, ursolic acid, apigenin and rosameric acid and appreciable quantities of eugenol which exhibit anti-oxidant and antiinflammatory activities. Two flavonoids viz. orientin and vicenin from aqueous leaf extract have been isolated that provide protection against radiation induced chromosomal damage in human blood lymphocytes. ${ }^{[7,8]}$

\section{MATERIALS AND METHODS}

\section{Collection and Authentication of Plant Material}

Leaves of Ocimum sanctum Linn. (OS) were collected from local areas of Dibrugarh in the month of April-May, identified and authenticated by Dr. L. R. Saikia, Department of Life Science, Dibrugarh University, Assam (Voucher specimen no. DULSc 448). A voucher specimen was deposited in the herbarium of the institute.

\section{Preparation of the Plant Extract}

Fresh leaves of Ocimum sanctum are washed thoroughly with distilled water, air dried, powdered. About 850 gms of powder was obtained, which was then packed into a Soxhlet apparatus and extraction was done by continuous hot percolation using ethanol $(95 \% \mathrm{v} / \mathrm{v})$. The extract was concentrated using a rotary evaporator. It was further concentrated and dried in desiccators. The final yield of ethanolic extract was found to be $7.24 \%(\mathrm{w} / \mathrm{w}) .{ }^{[9]}$ The extract collected was stored in air tight glass containers in refrigerator at $2-8^{\circ} \mathrm{C}$ for further use in experiments.

\section{Phytochemical Analysis}

EEOS was subjected to qualitative phytochemical analysis of alkaloids, flavonoids, tannins, saponins, sterols, terpenoids as per standard methods.[10]

\section{Drugs and Chemical Used}

Alloxan monohydrate was obtained from G. S. Chemical testing lab and allied industries, New Delhi. Crude powder of Glibenclamide was obtained from Ranbaxy Laboratories Ltd.

\section{Experimental Animals}

Healthy Wistar albino rats (Rattus norvegicus) 7-8 weeks old, weighing 150-200 grams were taken from Central Animal House, Gauhati Medical College (Registration No. IAEC Regd. No. 351/CPCSEA-3/1/2001). The animals were housed in standard cages under standard conditions of 12 hours light and dark cycle and normal room temperature. Animals were fed with normal diet and water ad libitum before starting the study permission from the Institutional Animal Ethics Committee was taken. The study was conducted according to CPCSEA guidelines.

\section{Acute Oral Toxicity Test}

Acute oral toxicity test was done following OECD guidelines 425 (Up and down method). EEOS was found safe at 2000 $\mathrm{mg} / \mathrm{kg}$ dose.[11] Two arbitrary doses $250 \mathrm{mg} / \mathrm{kg}$ and 500 $\mathrm{mg} / \mathrm{kg}$ were selected for the study.

\section{Experimental Design}

Animals are randomly assigned into five groups with six animals in each group $(n=6)$.

Group A - Normal group (Given only saline $10 \mathrm{~mL} / \mathrm{kg} /$ day). Group B - Diabetic control (Given saline $10 \mathrm{~mL} / \mathrm{kg}+$ Alloxan). Group C - Diabetic treated with EEOS $(250 \mathrm{mg} / \mathrm{kg} /$ day). Group D - Diabetic treated with EEOS (500 mg/kg/day). Group E- Diabetic treated with Glibenclamide $(5 \mathrm{mg} / \mathrm{kg} /$ day).

Standard drug Glibenclamide $(5 \mathrm{mg} / \mathrm{kg}$ ) and ethanolic extract of Ocimum sanctum (EEOS) were given orally with the help of feeding cannula daily for 4 weeks.

\section{Induction of Diabetes in Experimental Animals}

Wistar albino rats were made diabetic by a single intraperitoneal injection of Alloxan monohydrate (150 $\mathrm{mg} / \mathrm{kg})_{.[12]}$ Alloxan is first weighed individually for each animal according to the body weight and then solubilised with $0.2 \mathrm{~mL}$ saline ( $154 \mathrm{mM} \mathrm{NaCl}$ ) just prior to injection. Two days after alloxan injection, rats with plasma glucose levels > $200 \mathrm{mg} / \mathrm{dL}$ were included in the study. Treatment with plant extract was started 48 hours after alloxan injection.[13]

\section{Collection of Blood Sample and Blood Glucose Estimation} Blood samples were drawn from tail tip of rat at weekly intervals till the end of the study (i.e. 4 weeks). Fasting blood glucose estimation and body weight measurement were done after 48 hours, $7^{\text {th }}, 14^{\text {th }}, 21^{\text {st }}$ and $28^{\text {th }}$ day. Blood glucose estimation was done by One Touch electronic glucometer; Johnson and Johnson Company, USA using glucose strip. On the $28^{\text {th }}$ day, blood was collected from retro-orbital plexus under mild ether anaesthesia after overnight fasting and fasting blood sugar and other biochemical parameters were estimated. Total cholesterol was estimated by CHOP/PAP method,[14] TG by GPO/PAP method,[15] HDL-C measured by PEG/CHOD-PAP method,[16] LDL-C measured by Friedwald's Formula.[17]

\section{Statistical Analysis}

All the values of body weight, fasting blood sugar and lipid profile were expressed as mean \pm standard error of mean (S.E.M) and analysed by using one-way analysis of variance (ANOVA) followed by Dunnett's multiple comparison test. ' $\mathrm{P}$ ' value of $<0.05$ were considered significant.

\section{RESULTS}

\section{Acute Toxicity Test}

No mortality was recorded among the rats at a dose of 2000 $\mathrm{mg} / \mathrm{kg}$. Hence, EEOS at doses of $250 \mathrm{mg} / \mathrm{kg}$ and $500 \mathrm{mg} / \mathrm{kg}$ was found to be safe. This selected dose was also confirmed by Subramani Parasuraman et al.[18] 


\section{Phytochemical Analysis}

Phytochemical analysis of leaves of Ocimum sanctum Linn. has revealed the presence of alkaloids, flavonoids, glycosides, saponins, tannins and terpenoids.

\section{Effect of Extract Treatment on the Body Weight}

The results of body weight are shown in Table 1 . In normal (Control) group, there is slight increase in body weight. In the diabetic control group, there is significant reduction in body weight compared to group $A$ and in groups $C, D$ and $E$ there is significant increase in body weight compared to Group B.

\begin{tabular}{|c|c|c|}
\hline Group & Day 1 & Day 28 \\
\hline Normal Control & $154.8 \pm 1.515$ & $156.7 \pm 1.229$ \\
\hline Diabetic Control & $155.8 \pm 0.9458^{\mathrm{a}}$ & $134.0 \pm 0.894^{\mathrm{a}}$ \\
\hline $\begin{array}{c}\text { Diabetic Test } \\
(250 \mathrm{mg} / \mathrm{kg})\end{array}$ & $155.2 \pm 0.8724^{\mathrm{b}}$ & $141.7 \pm 0.802^{\mathrm{b}}$ \\
\hline $\begin{array}{c}\text { Diabetic Test } \\
(500 \mathrm{mg} / \mathrm{kg})\end{array}$ & $156.0 \pm 1.125^{\mathrm{b}}$ & $146.7 \pm 1.606^{\mathrm{b}}$ \\
\hline Diabetic Standard & $155.5 \pm 0.9574^{\mathrm{b}}$ & $147.7 \pm 0.918^{\mathrm{b}}$ \\
\hline $\begin{array}{c}\text { Table 1. Effect of Ethanolic Extract of Leaves of } \\
\text { Ocimum sanctum on Body Weight (Grams) } \\
\text { of Alloxan-Induced Diabetic Rats }\end{array}$ \\
\hline
\end{tabular}

All values are expressed in mean \pm SEM. Analysed by OneWay ANOVA followed by Dunnett's multiple comparison tests $\mathrm{a}=\mathrm{p}<0.05$ when compared to normal control Group $\mathrm{b}=\mathrm{p}<$ 0.05 when compared to diabetic control group.

\section{Effect of Extract Treatment on Fasting Blood Sugar Level}

The results of fasting blood sugar are shown in Table 2. On repeated administration of the extract for 4 weeks, a significant $(p<0.05)$ decrease in blood sugar was found in Groups C, D and E compared to Group B. Group B showed significant rise in blood sugar as compared to Group A.

\begin{tabular}{|c|c|c|c|c|c|}
\hline \multirow{2}{*}{ Group } & \multicolumn{5}{|c|}{ Mean Blood Glucose Level (mg/dL) } \\
\cline { 2 - 6 } & $\begin{array}{c}\text { After 48 } \\
\text { Hours }\end{array}$ & Day 7 & $\begin{array}{c}\text { Day } \\
\mathbf{1 4}\end{array}$ & $\begin{array}{c}\text { Day } \\
\mathbf{2 1}\end{array}$ & $\begin{array}{c}\text { Day } \\
\mathbf{2 8}\end{array}$ \\
\hline Normal & $87.67 \pm$ & $87.33 \pm$ & $88.83 \pm$ & $90.33 \pm$ & $91.83 \pm$ \\
Control & 1.17 & 1.52 & 1.30 & 1.22 & 1.01 \\
\hline Diabetic & $210.3 \pm$ & $225.7 \pm$ & $243.3 \pm$ & $240.3 \pm$ & $246.5 \pm$ \\
Control & $0.80^{\mathrm{a}}$ & $0.802^{\mathrm{a}}$ & $0.95^{\mathrm{a}}$ & $0.95^{\mathrm{a}}$ & $1.78^{\mathrm{a}}$ \\
\hline Diabetic Test & $222 \pm$ & $168.7 \pm$ & $141.8 \pm$ & $121.3 \pm$ & $104.7 \pm$ \\
$(250 \mathrm{mg} / \mathrm{kg})$ & $1.65^{\mathrm{b}}$ & $3.007^{\mathrm{b}}$ & $1.27^{\mathrm{b}}$ & $1.33^{\mathrm{b}}$ & $1.52^{\mathrm{b}}$ \\
\hline Diabetic Test & $220.7 \pm$ & $170.3 \pm$ & $133.3 \pm$ & $116.3 \pm$ & $103.7 \pm$ \\
$(500 \mathrm{mg} / \mathrm{kg})$ & $1.52^{\mathrm{b}}$ & $1.49 \mathrm{~b}$ & $1.43^{\mathrm{b}}$ & $2.49^{\mathrm{b}}$ & $1.82^{\mathrm{b}}$ \\
\hline Diabetic & $219.7 \pm$ & $161 \pm$ & $135.3 \pm$ & $116.7 \pm$ & $99.67 \pm$ \\
Standard & $1.40^{\mathrm{b}}$ & $3.75^{\mathrm{b}}$ & $3.49^{\mathrm{b}}$ & $2.90^{\mathrm{b}}$ & $0.95^{\mathrm{b}}$ \\
\hline Table 2. Effect of Ethanolic Extract of Leaves of Ocimum \\
sanctum on Fasting Blood Glucose Level \\
of Alloxan-Induced Diabetic Rats \\
\hline
\end{tabular}

All values are expressed in Mean \pm SEM. Analysed by OneWay ANOVA followed by Dunnett's multiple comparison tests. $\mathrm{A}=\mathrm{p}<0.05$ when compared to normal control group $\mathrm{b}$ $=\mathrm{p}<0.05$ when compared to diabetic control group.

\section{Effect of Extract Treatment on Fasting Lipid Profile}

The results of fasting lipid profile are shown in Table 3. On repeated administration of the extract for 4 weeks, a significant $(\mathrm{p}<0.05)$ decrease in total cholesterol, serum LDL, serum TG and significant increase in serum HDL was found in Groups C, D and E compared to Group B. Group B showed significant rise in total cholesterol, serum LDL and serum TG and decrease in serum HDL as compared to Group A.

\begin{tabular}{|c|c|c|c|c|}
\hline Group & $\begin{array}{c}\text { Serum Total } \\
\text { Cholesterol } \\
\text { (mg/dL) }\end{array}$ & $\begin{array}{c}\text { Serum } \\
\text { TG } \\
\text { (mg/dL) }\end{array}$ & $\begin{array}{c}\text { Serum } \\
\text { HDL } \\
\text { (mg/dL) }\end{array}$ & $\begin{array}{c}\text { Serum } \\
\text { LDL } \\
\text { (mg/dL) }\end{array}$ \\
\hline Normal & $67.17 \pm$ & $81.83 \pm$ & $25.50 \pm$ & $25.30 \pm$ \\
Control & 2.056 & 2.626 & 1.478 & 1.185 \\
\hline Diabetic & $135.3 \pm$ & $151.2 \pm$ & $17.67 \pm$ & $87.43 \pm$ \\
Control & $1.745^{\mathrm{a}}$ & $1.195^{\mathrm{a}}$ & $0.667^{\mathrm{a}}$ & $1.926^{\mathrm{a}}$ \\
\hline Diabetic Test & $94.17 \pm$ & $92.67 \pm$ & $33.33 \pm$ & $41.87 \pm$ \\
$(250 \mathrm{mg} / \mathrm{kg})$ & $2.344^{\mathrm{b}}$ & $1.308^{\mathrm{b}}$ & $1.308^{\mathrm{b}}$ & $2.720^{\mathrm{b}}$ \\
\hline Diabetic Test & $87.67 \pm$ & $89.50 \pm$ & $35.33 \pm$ & $34.93 \pm$ \\
(500 mg/kg) & $1.202^{\mathrm{b}}$ & $1.648^{\mathrm{b}}$ & $1.926^{\mathrm{b}}$ & $1.153^{\mathrm{b}}$ \\
\hline Diabetic & $88.50 \pm$ & $89.33 \pm$ & $35.33 \pm$ & $35.30 \pm$ \\
Standard & $1.875^{\mathrm{b}}$ & $2.186^{\mathrm{b}}$ & $1.606^{\mathrm{b}}$ & $1.865^{\mathrm{b}}$ \\
\hline \multicolumn{6}{|c|}{ Table 3. Effect of Leaves of Ocimum sanctum } \\
on Lipid Profile of Alloxan-Induced Diabetic Rats \\
\hline
\end{tabular}

All values are expressed in mean \pm SEM. Analysed by OneWay ANOVA followed by Dunnett's multiple comparison tests; $\mathrm{a}=\mathrm{p}<0.05$ when compared to normal control group $\mathrm{b}$ $=\mathrm{p}<0.05$ when compared to diabetic control group.

\section{DISCUSSION}

Alloxan monohydrate is commonly used to induce noninsulin dependent diabetes mellitus in many experimental animals. The mechanism of action of Alloxan has been thoroughly studied. Alloxan, a cytotoxic agent induces diabetes in various animal species through destruction of islets of Langerhans of the pancreas. After administration it is rapidly and selectively taken up by the $\beta$ cells of the pancreas, following which there is formation of redox cycle for generation of Reactive Oxygen Species (ROS), superoxide radicals and hydrogen peroxide. ${ }^{[19]}$ Another mechanism is the effect of ROS on the DNA of the pancreatic islets. The fragmentation of DNA takes place in the beta cells exposed to alloxan that causes DNA damage, which stimulates poly ADPribosylation, a process participating in DNA repair. Antioxidants like superoxide dismutase, catalase and the nonenzymatic scavengers of hydroxyl radicals have been found to protect against alloxan toxicity.[20] In addition, the disturbances of intracellular calcium homeostasis has also been responsible for diabetogenic action of alloxan, as it elevates cytosolic free $\mathrm{Ca}^{2+}$ concentration in the beta cells of the pancreatic islets. Increased concentration of $\mathrm{Ca}^{2+}$ and ROS ultimately damages the beta cells of the pancreatic islets.[21]

In our study, we observed that EEOS decreased blood glucose in alloxan-induced diabetic rats comparable with the oral hypoglycaemic agent, Glibenclamide (a sulphonylurea). The mechanism of action of the extract could be similar to that of sulphonylurea, which promote insulin secretion by closure of K+ ATP (Adenosine 5-monophosphate) channels. This results in membrane depolarisation and increased $\mathrm{Ca}^{2+}$ influx, which is a key initial step in insulin secretion. [22,23]

The antidiabetic effect of EEOS also may be due to the effect of active flavonoids, phenols, steroids and saponins which scavenges free radicals liberated by alloxan in diabetic rats. Similar hypoglycaemic effects have been reported for several plants that contain flavonoids.[24]

Apart from the regulation of carbohydrate metabolism, insulin also plays an important role in the metabolism of lipids. Insulin is a potent inhibitor of lipolysis, because it inhibits the activity of hormone sensitive lipases in adipose tissue and suppresses the release of free fatty acid into circulation. As a result of insulin resistance in adipose tissue, lipolysis and free fatty acid flux from the adipocytes are increased, leading to increased lipid (very low density 
lipoprotein and triglyceride) synthesis in the hepatocytes. This is responsible for dyslipidaemia found in type 2 Diabetes mellitus.[25]

The hypocholesterolaemic activity of EEOS may be due to presence of flavonoids and related phenolic compounds. Similar results has also been reported by Khan et al.[26] Flavonoids significantly increased LDL receptor mRNA levels, which in turn increase hepatic uptake and degradation of LDL causing a decrease in serum LDL levels. ${ }^{[27,28]}$

\section{CONCLUSION}

It is thus concluded that EEOS at a dose of $250 \mathrm{mg} / \mathrm{kg}$ and $500 \mathrm{mg} / \mathrm{kg}$ body weight produced significant antidiabetic activity in alloxan-induced NIDDM in rats. Also it produced significant antihyperlipidaemic effect and thus proves to be effective in preventing and managing complications of diabetes, i.e. hyperlipidaemia and related consequences. Therefore. Ocimum sanctum leaves could be a novel antidiabetic agent and also a dietary adjunct in the management of diabetes mellitus. However, further studies have to be undertaken to find out the exact mechanism of antidiabetic activity of Ocimum sanctum.

\section{ACKNOWLEDGEMENT}

The authors are thankful to Dr. L. R. Saikia, Professor, Department of Life Sciences, Dibrugarh University, Assam for helping in authentication of the plant.

\section{REFERENCES}

1. Bennett PH. Definition, diagnosis and classification of diabetes mellitus and impaired glucose tolerance. Joslin's diabetes mellitus. $13^{\text {th }}$ edn. New Delhi: B I Waverly Pvt Ltd, 1996:193-200.

2. Preeti Km, Verma AB, Gautam B, et al. Medicinal plants with antidiabeticpotentiall-a review on ten years of research (2003-2013). International Journal for Pharmaceutical Research Scholars 2014;3(1):264-83.

3. IDF Diabetes altas. International Diabetes Federation. $7^{\text {th }}$ edn: 2015:1-144. (http://www.idf.org/).

4. Rizvi SI, Mishra N. Traditional Indian medicines used for the management of diabetes mellitus. Journal of Diabetes Research 2013;2013:712092.

5. Joseph B, Nair VM. Ethanopharmacological and phytochemical aspects of Ocimum sanctum Linn-the elixir of life. British Journal of Pharmaceutical Research 2013;3(2):273-92.

6. Pattanayak P, Behera $\mathrm{P}$, Das D, et al. Ocimum sanctum Linn. A reservoir plant for therapeutic application: an overview. Pharmacognosy Review 2010;4(7):95-105.

7. Mandal A, Reddy PJM. A review of phytochemical and pharmacological uses of Ocimum sanctum Linn. World Journal of Pharmaceutical Research 2015;4(7):1535-49.

8. Rahman S, Islam R, Kamruzzaman Md, et al. Ocimum sanctum L. A review of phytochemical and pharmacological profile. American Journal of Drug Discovery and Develpoment 2011:1-5.

9. Nairn JG. Solutions, emulsions, suspension and extracts. In: Gennaro A, Marderosian AD, Hanson GR, et al. The science and practice of pharmacy. $20^{\text {th }}$ edn. Philadelphia: Lippincott Williams and Wilkins 2000:721-52.

10. Tiwari P, Kumar B, Kaur $M$, et al. Phytochemical screening and extraction: a review. International Pharmaceutica Sciencia 2011;1(1):98-106.

11. Organisation for economic co-operation and development (OECD). Health effects Test no. 425: Acute oral toxicity up and down procedure. OECD Guidelines for testing of chemicals. Section 4. France: OECD publishing 2006:1-27.

12. Kulkarni SK. Handbook of experimental pharmacology. commonly used drugs, their dosers and nature of action in laboratory animals. 3rd edn. 2005:190-5.

13. Etuk EU. Animal models for studying diabetes mellitus. Agriculture and Biology Journal of North America 2010;1(2):130-4.

14. Allain CC, Poon LS, Chan CS, et al. Enzymatic determination of total serum cholesterol. Clin Chem 1974;20(4):470-5.

15. Fossati P, Prencipe L. Serum triglycerides determined colorimetrically with an enzyme that produces Hydrogen peroxide. Clin Chem 1982;28(10):2077-80.

16. Grillo F, Izzo C, Mazzotti G, et al. Improved method for determination of high-density lipoprotein cholesterol ll. Enzymatic determination of cholesterol in high-density lipoprotein fractions with a sensitive reagent. Clin Chem 1981;27(3):375-9.

17. Friedewald WT, Levy RI, Freidrickson DS. Estimation of the concentration of LDL cholesterol in plasma, without the use of preparative ultracentrifuge. Clin Chem 1972;18(6):499-502.

18. Parasuraman $\mathrm{S}$, Balamurugan $\mathrm{S}$, Christapher $\mathrm{PV}$, et al. Evaluation of antidiabetic and antihyperlipidaemic effect of hydroalcoholic extract of leaves of Ocimumtenuiflorum (Lamiaceae) and prediction of biological activity of its phytoconstituents. Pharmacognosy Research 2015;7(2):156-65.

19. Szkudelski T. The mechanism of alloxan and streptozotocin action in beta cells of the rat pancreas. Physiol Res 2001;50(6):537-46.

20. Park BH, Rho HW, Park JW, et al. Protective mechanism of glucose against alloxan-induced pancreatic beta-cell damage. Biochem Biophysics RsCommun 1995;210(1):16.

21. Ebelt H, Peschke D, Bromme HJ, et al. Influence of melatonin on free radical-induced changes in rat pancreatic beta-cells in vitro. J Pineal Res 2000;28(2):6572.

22. Davis SN. Insulin, oral hypoglycaemic agents and the pharmacology of the endocrine panceas. Goodman and Gilman's The pharmacological basis of therapeutics. 11 th edn. New York: McGraw Hill 2005:1613-45.

23. Hannan JM, Marenah L, Ali L, et al. Ocimum sanctum leaf extract stimulates insulin secretion from perfused pancreas, isolated islets and clonal pancreatic beta-cells. Journal Endocrinology 2006;189(1):127-36.

24. Hannan JMA, Ojo 00, Ali L, et al. Action underlying antidiabetic effects of Ocimum sanctum leaf extract in animal model of Type 1 and Type 2 Diabetes. European Journal of Medicinal Plants 2015;5(1):1-12.

25. Powers AC. Diabetes mellitus: diagnosis, classification and pathophysiology. Harrison's principles of internal medicine. Vol 2. $19^{\text {th }}$ edn. McGraw Hill Education 2015:2399-2406.

26. Khan MRI, Islam MA, Hossain MS. Antidiabetic effects of the different fractions of ethanolic extracts of ocimum sanctum in normal and alloxan induced diabetic rats. Journal of Scientific Research 2010;2(1):158-68.

27. Wilcox LJ, Borradaile NM, de Dreu LE, et al. Secretion of hepatocyte apo B is inhibited by flavonoids, naringenin and hesperetin, via reduced activity and expression of ACAT 2 and MTP. Journal Lipid Res 2001;42(5):725-34.

28. Gross M. Flavonoids and cardiovascular disease. Pharmaceutical Biology 2004;42(Suppl 1):21-35. 